\title{
PEMODELAN PENJADWALAN LINIER DENGAN ALOKASI SUMBER DAYA MANUSIA PADA PROYEK PERUMAHAN
}

\author{
Hedwig A Tan ${ }^{1}$, Ratna S Alifen²
}

\begin{abstract}
ABSTRAK: Metode penjadwalan linier cocok untuk proyek dengan aktivitas sederhana, dan repetitif dengan jumlah unit yang tipikal, seperti proyek jalan, irigasi, tunnel, apartment, dan perumahan sederhana. Pada penelitian ini dilakukan pemodelan penjadwalan linier proyek pembangunan perumahan sebanyak 50 unit tipikal. Simulasi alokasi sumber daya manusia dan penggunaan buffer agar penggunaan sumber daya manusia dapat seefisien mungkin. Hasil penelitian diperoleh bahwa simulasi ke-8 dengan menggunakan buffer memiliki durasi 314 hari dengan 18 kelompok kerja, apabila dibandingkan dengan simulasi ke-9 tanpa menggunakan buffer memiliki durasi 180 hari dan idle time 134 hari inefisiensi 1522 orang hari.
\end{abstract}

Kata kunci: perumahan, penjadwalan linier, simulasi sumber daya manusia.

ABSTRACT: Linear scheduling method is suitable for projects with repetitive activities, as well as tipical mass product units such as a road, apartment, and residential housings. In this research linear schedule modeling was carried out on residential typical housings project of 50 units. The simulation of linear scheduling is to minimize the idle times by using time buffers and human resources allocation so that the usage of human resources can be as efficient as possible.

The research findings show that the 8th simulation by using buffers has a project duration of 314 days were chosen with 18 working groups, compares to 9th simulation without buffers that has a duration of 180 days and 134 days of idle time which with 1522 man day of inefficient.

Keywords: housing, scheduling linear, human resources simulation.

\section{PENDAHULUAN}

Pada pelaksanaan proyek konstruksi, metode penjadwalan berperan penting dalam mengatur waktu pelaksanaan proyek dan sumber daya manusia, pada proyek multi unit yang mengutamakan kuantitas dengan memaksimalkan alokasi sumber daya manusia. Metode penjadwalan linier merupakan salah satu metode penjadwalan yang cocok untuk jenis proyek massal dengan kegiatan yang repetitif. Pada penelitian ini akan direncanakan penjadwalan linier untuk proyek pembangunaan perumahan dinas guru SMAN 1 Kaimana Provinsi Manokwari yang terdiri dari 50 unit tipikal.

\footnotetext{
${ }^{1}$ Mahasiswa Pascasarjana Magister Teknik Sipil UK Petra, h_3d_w19@yahoo.com

2 Dosen Pascasarjana Magister Teknik Sipil UK Petra, alifrat@petra.ac.id
} 
Pada penjadwalan linier dilakukan simulasi dengan penggunaan buffer dan alokasi sumber daya manusia dengan meminimalkan waktu tenggang (idle time), sehingga sumber daya manusia dapat digunakan secara efisien. Penelitian ini dapat memberikan suatu alternatif metode penjadwalan yang cocok untuk diterapkan pada proyek perumahan massal ini yang telah diselesaikan dengan metode Bar Chart, manfaat penelitian ini adalah agar metode penjadwalan linier dapat digunakan pada proyek sejenis di waktu mendatang.

\section{LANDASAN TEORI}

Suatu penjadwalan proyek akan berlangsung sesuai yang direncanakan apabila didukung dengan ketersedian sumber daya manusia di lokasi proyek. Sebaliknya, tujuan dari suatu proyek konstruksi akan dapat tercapai bila proses planning dan scheduling dapat dilakukan dengan baik. Hal ini karena proyek konstruksi merupakan suatu rangkaian proses dari seluruh aktivitas sehingga perlu mengatur alokasi sumber daya manusia agar tercapai sumber daya manusia yang efisien dan durasi yang efektif. Sumber daya manusia dikatakan efisien apabila pada suatu aktivitas sumber daya manusia bekerja secara berkelanjutan antara unit yang satu dengan unit yang lain, sehingga dapat meminimalkan idle time atau non-productive time.

Ketepatan dalam menyelesaikan suatu proyek adalah merupakan indikator kesuksesan suatu proyek disamping biaya, keselamatan kerja dan kualitas, namun dalam proyek repetitif lebih difokuskan pada kuantitas, dimana unit yang dikerjakan merupakan produk massal. Konsep dasar metode penjadwalan linier adalah penyajian dalam diagram grafik yang menunjukkan hubungan antara unit (kuantitas) dan waktu dari setiap aktivitas (Leong \& Kass, 2008). Metode penjadwalan linier merupakan metode yang cocok digunakan pada proyek yang memiliki aktivitas berulang dengan jenis aktivitas yang sederhana, seperti pembangunan dermaga, jetty, jalan raya, dan perumahan sederhana.

Terminologi dalam metode penjadwalan linier, yaitu :

A. Interupsi

Interupsi adalah penghentian aktivitas untuk waktu tertentu yang ditunjukkan dengan garis mendatar pada garis linier aktivitas (Gambar 1). Penyebabnya, yaitu : sumber daya yang terhenti, kesulitan teknis dan lain-lain.

B. Buffer

Buffer adalah pemberian penengah antara dua aktivitas untuk menghindari interfensi

(Gambar 2), sedangkan buffer dapat berupa time buffer adalah pemberian jeda waktu antara dua aktivitas, dan Space buffer adalah penengah antara dua unit (Gambar 3). Time buffer terbagi dua jenis yaitu start buffer adalah jeda waktu yang diberikan pada start suatu aktivitas dan end buffer kebalikan dari start buffer (Gambar 4).

C. Interfensi

Interfensi adalah perpotongan antara dua aktivitas pada suatu titik (Gambar 2).

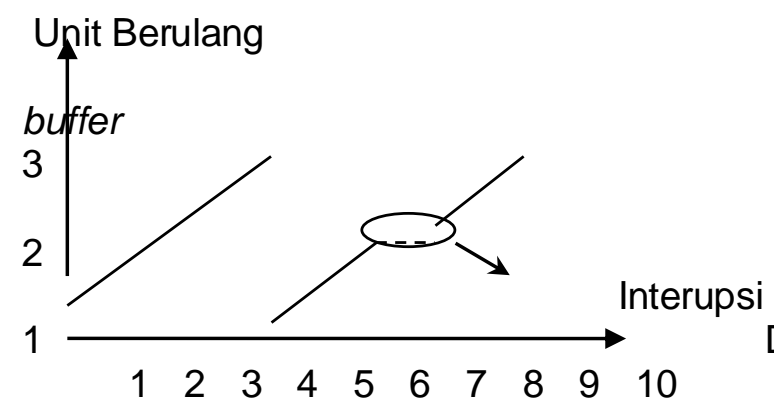

Gambar 1. Interupsi (Harris dan loannou, 1998).

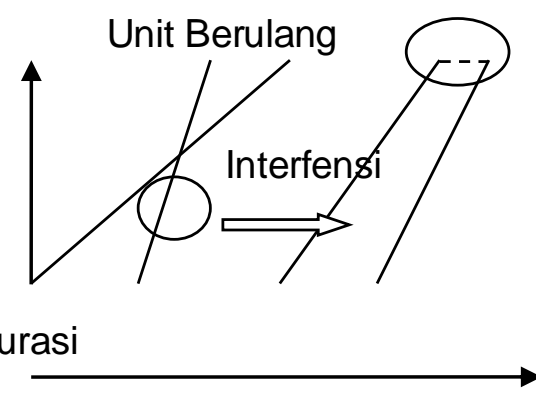

Durasi

Gambar 2. Interfensi dan Time Buffer 

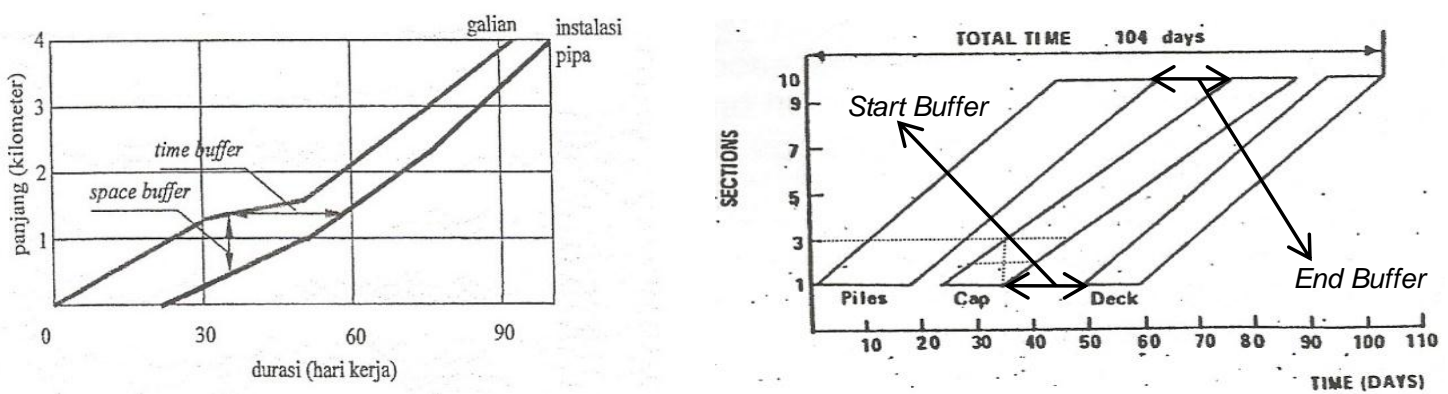

Gambar 3. MPL dengan Buffer (Pilcher, 1992). Gambar 4. Start Buffer \& End Buffer (Pilcher, 1992)

\section{Alokasi Sumber Daya Manusia}

Dalam menentukan alokasi sumber daya manusia yang efisien maka terlebih dahulu perlu mengetahui jumlah idle time dari setiap aktivitas. Langkah awal adalah menghitung durasi yang diperlukan untuk menyelesaikan proyek dengan jumlah unit dan tingkat produktivitas tertentu.

$$
\mathrm{t}_{2}=\frac{\left(\mathrm{Q}_{2}-\mathrm{Q}_{1}\right)}{\mathrm{m}}+\mathrm{t}_{1}
$$

Rumus untuk menghitung tingkat produktivitas :

$$
\mathrm{m}=\frac{\mathrm{F}}{\mathrm{d}}
$$

Dimana :

$\mathrm{t}_{1}=$ Durasi yang dibutuhkan untuk menyelesaikan unit ke-1 (hari).

$\mathrm{t}_{2}=$ Durasi yang dibutuhkan untuk menyelesaikan jumlah unit yang akan dibangun (hari).

$\mathrm{Q}_{1}=$ Unit pertama (unit).

$\mathrm{Q}_{2}=$ Jumlah unit yang akan dibangun (unit).

$\mathrm{m}=$ Tingkat produktivitas / hand over rate (jumlah unit/hari).

\section{E. Idle Time}

Inefisiensi atau idle time adalah waktu yang non-produktif atau waktu tunggu yang perlu di minimalkan sehingga sumber daya menjadi efisien (Gambar 5).

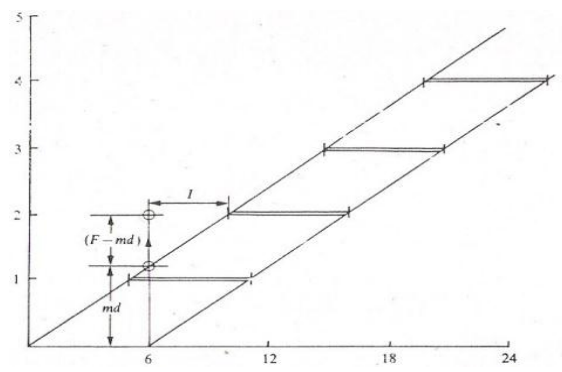

Gambar 5. Non-Productive Time (Pilcher, 1992).

Formula untuk menghitung idle time :

Dimana :

$$
I=\frac{(F-m \cdot d)}{m}=\frac{F}{m}-d
$$

$\mathrm{d}=$ Durasi aktivitas (hari).

$\mathrm{I}$ = Idle time atau non-productive time pada suatu aktivitas berulang (hari).

$\mathrm{F}=$ Jumlah kelompok kerja (group).

$\mathrm{m}=$ Tingkat produktivitas / hand over rate (jumlah unit/hari). 


\section{METODE PENELITIAN}

Dalam menyusun penjadwalan linier, identifikasi aktivitas berdasarkan pada aktivitas kritis hasil dengan metode CPM (Critical path method). Data pendukung adalah :

1. Dokumen Proyek

Gambar proyek yang diperoleh berupa : denah, tampak, potongan, dan detail. Gambar proyek diperlukan untuk menghitung volume pekerjaan, identifikasi dan urutan aktivitas.

2. Standart Nasional Indonesia (SNI)

Dalam penelitian ini menggunakan SNI untuk menentukan jumlah pekerja dalam 1 kelompok kerja dan tingkat produktivitas pekerja dalam menyelesaikan suatu aktivitas.

\section{PROSES PEMBUATAN PENJADWALAN LINIER}

\subsection{Analisis Data}

Studi kasus pada proyek pembangunan perumahan dinas guru SMA N.1 Kaimana di Kabupaten Kaimana Provinsi Manokwari (Papua Barat) dengan luas bangunan setiap kopel adalah $107 \mathrm{~m}^{2}$. Dalam melakukan perencanaan penjadwalan dengan metode CPM ada beberapa tahapan, yaitu : (1) identifikasi aktivitas, (2) estimasi durasi aktivitas, (3) urutan aktivitas dan (4) penjadwalan. Aktivitas kritis yang diperoleh dari hasil CPM (Gambar 6) adalah aktivitas untuk penjadwalan linier. Berikut penjadwalan CPM :

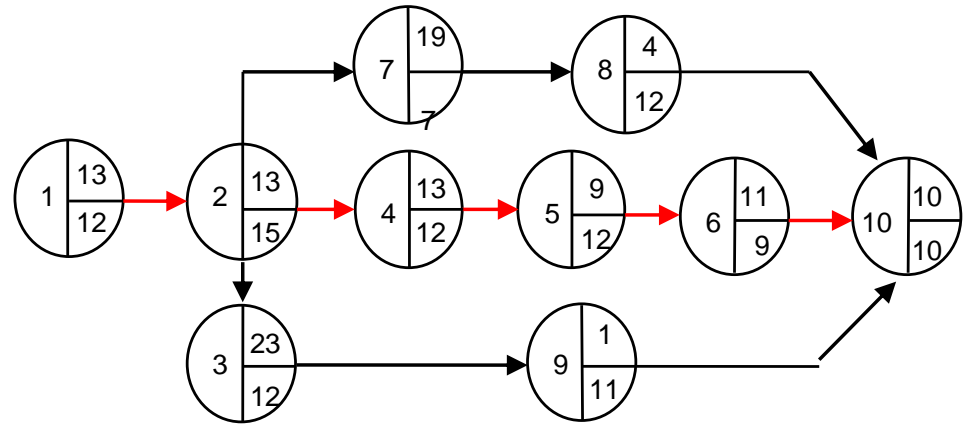

Gambar 6. Network Hasil CPM.

\begin{tabular}{|r|l|}
\hline \multicolumn{1}{|r|}{ ID } & Activity / jenis pekerjaan \\
\hline 1 & $\begin{array}{l}\text { Pekerjaan Tanah dan } \\
\text { Pondasi }\end{array}$ \\
\hline 2 & Pekerjaan Struktur Beton \\
\hline 3 & Pekerjaan Dinding \\
\hline 4 & Pekerjaan Atap \\
\hline 5 & Pekerjaan Plafond \\
\hline 6 & Pekerjaan Keramik \\
\hline 7 & Pekerjaan Pintu dan Jendela \\
\hline 8 & Pekerjaan Sanitasi \\
\hline 9 & Pekerjaan Listrik \\
\hline 10 & Pekerjaan Cat dan Finishing \\
\hline
\end{tabular}
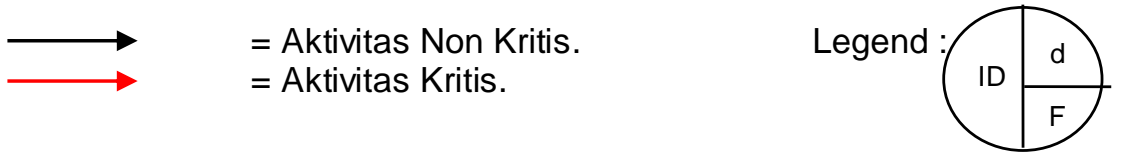

ID = Identifikasi aktivitas

$\mathrm{d}=$ Durasi

$\mathrm{F}=$ Jumlah kelompok kerja

\subsection{Penjadwalan Linier}

Pada penjadwalan linier menggunakan 6 aktivitas kritis yang diperoleh dari analisis CPM (Gambar 6). Adanya durasi masing-masing aktivitas yang beragam dengan digunakan jumlah kelompok kerja $\mathrm{F}=1$ dan dikerjakan secara berkelanjutan antar aktivitas yang satu dengan aktivitas lainnya maka akan terjadi interfensi antar aktivitas, sehingga simulasi ini tidak dapat diterapkan dilapangan (Gambar 7). 


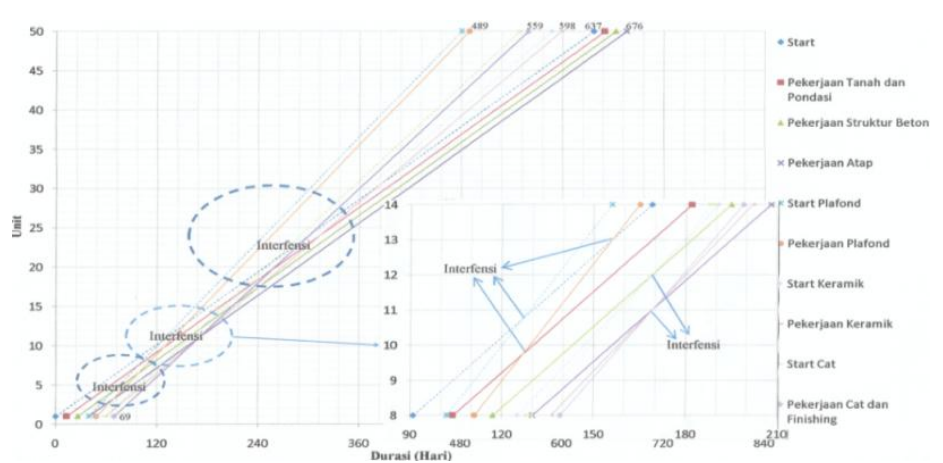

Gambar 7. Simulasi dengan 1 Kelompok Kerja $(F=1)$.

Untuk menghindari terjadinya interfensi terdapat dua macam model simulasi penjadwalan linier, yaitu :

(1) Simulasi penjadwalan linier dengan time buffer.

(2) Simulasi penjadwalan linier tanpa time buffer.

\subsubsection{Simulasi Penjadwalan Linier dengan Time Buffer}

Pada simulasi ini bertujuan untuk menghilangkan idle time dan interfensi dengan memberi time buffer, karena setiap aktivitas memiliki durasi yang berbeda sehingga dalam suatu simulasi setiap aktivitas menggunakan nilai $m$ yang beragam. Dalam simulasi ini yang menjadi acuan adalah pekerjaan tanah dan pondasi, pekerjaan struktur beton, dan pekerjaan atap. Hal ini karena nilai $\mathrm{m}$ dari ketiga aktivitas tersebut memiliki nilai $\mathrm{m}$ terendah akibat durasi yang besar.

Pada Tabel 1 dapat disimpulkan bahwa dari semua simulasi penjadwalan linier dengan menggunakan buffer yang dianggap mampu mengurangi durasi penyelesaian 50 unit kopel secara signifikan, sehingga memperoleh penggunaan SDM yang efisien adalah simulasi ke-8, karena penambahan jumlah kelompok kerja di imbangi dengan pengurangan durasi yang signifikan (Tabel 2 dan Gambar 8).

Tabel 1. Rangkuman Simulasi Penjadwalan Linier Menggunakan Buffer.

\begin{tabular}{|c|c|c|c|c|c|c|c|c|c|}
\hline $\begin{array}{c}\text { Simu- } \\
\text { lasi } \\
\text { Ke.... }\end{array}$ & $\begin{array}{l}\text { Jumlah } \\
\text { kelompok } \\
\text { kerja }\end{array}$ & $\begin{array}{l}\text { d } \\
\text { Dur- } \\
\text { asi }\end{array}$ & $\begin{array}{c}d \\
\text { Durasi } \\
(<365 \\
\text { hari })\end{array}$ & $\begin{array}{c}\text { Rata-rata durasi } \\
\text { yang dapat } \\
\text { diminimalkan }\end{array}$ & $\begin{array}{l}\text { Simu- } \\
\text { lasi } \\
\text { Ke- }\end{array}$ & $\begin{array}{l}\text { Jumlah } \\
\text { kelompok } \\
\text { kerja }\end{array}$ & $\begin{array}{l}\text { d } \\
\text { Dur- } \\
\text { asi }\end{array}$ & $\begin{array}{c}d \\
\text { Durasi } \\
(<365 \\
\text { hari })\end{array}$ & $\begin{array}{c}\text { Rata-rata } \\
\text { durasi yang } \\
\text { dapat } \\
\text { diminimalkan }\end{array}$ \\
\hline & kelompok & hari & hari & $\begin{array}{l}\text { kelompok } \\
\text { kerja/hari }\end{array}$ & & kelompok & hari & hari & $\begin{array}{l}\text { kelompok } \\
\text { kerja/hari }\end{array}$ \\
\hline & & & $\begin{array}{c}804- \\
\text { (3) }\end{array}$ & $\begin{array}{c}(4) / \\
{[(2)-6]}\end{array}$ & & & & $\begin{array}{c}804 \text { - } \\
(3)\end{array}$ & $\begin{array}{c}(4) / \\
{[(2)-6]}\end{array}$ \\
\hline (1) & (2) & (3) & (4) & (5) & (1) & (2) & (3) & (4) & (5) \\
\hline ke-1 & 6 kelompok & 804 & - & - & ke-8 & 18 kelompok & 314 & 490 & 41 \\
\hline ke-2 & 8 kelompok & 706 & - & - & ke-9 & 17 kelompok & 559 & - & - \\
\hline ke-3 & 9 kelompok & 608 & - & - & ke-10 & 23 kelompok & 229 & 575 & 34 \\
\hline ke-4 & 14 kelompok & 388 & - & - & ke-11 & 22 kelompok & 257 & 547 & 35 \\
\hline ke-5 & 12 kelompok & 437 & - & - & ke-12 & 23 kelompok & 314 & 490 & 29 \\
\hline ke-6 & 14 kelompok & 559 & - & - & ke-13 & 29 kelompok & 197 & 607 & 27 \\
\hline ke-7 & 20 kelompok & 282 & 522 & 38 & ke-14 & 27 kelompok & 221 & 583 & 28 \\
\hline
\end{tabular}

Tabel 2. Hasil Perhitungan Simulasi ke-8 Menggunakan Buffer.

\begin{tabular}{|c|c|c|c|c|c|c|}
\hline \multirow{4}{*}{ ID } & \multirow{4}{*}{ Activity / jenis pekerjaan } & $\mathrm{d}$ & $\mathrm{M}$ & $\mathrm{F}$ & $\mathrm{T}_{1}$ & $\mathrm{~T}_{2}$ \\
\hline & & Durasi & Produktivitas & Group & Durasi unit ke-1 & Durasi unit ke-50 \\
\hline & & hari & jumlah unit/hari & group & hari & hari \\
\hline & & & $\mathrm{F} / \mathrm{d}$ & m.d & $\mathrm{T}_{2}-\left[\left(\mathrm{Q}_{2}-\mathrm{Q}_{1}\right) / \mathrm{m}\right]$ & {$\left[\left(\mathrm{Q}_{2}-\mathrm{Q}_{1}\right) / \mathrm{m}\right]+\mathrm{T}_{1}$} \\
\hline 1 & Pekerjaan Tanah dan Pondasi & 13 & 0,23077 & 3,0 & 13,0 & 225,3 \\
\hline 2 & Pekerjaan Struktur Beton & 13 & 0,23077 & 3,0 & 26,0 & 238,3 \\
\hline 4 & Pekerjaan Atap & 13 & 0,23077 & 3,0 & 39,0 & 251,3 \\
\hline 5 & Pekerjaan Plafond & 9 & 0,33333 & 3,0 & 113,3 & 260,3 \\
\hline 6 & Pekerjaan Keramik & 11 & 0,27273 & 3,0 & 124,3 & 304,0 \\
\hline 10 & Pekerjaan Cat dan Finishing & 10 & 0,30000 & 3,0 & 150,7 & 314,0 \\
\hline & Jumlah & 69 & & 18,0 & & \\
\hline
\end{tabular}




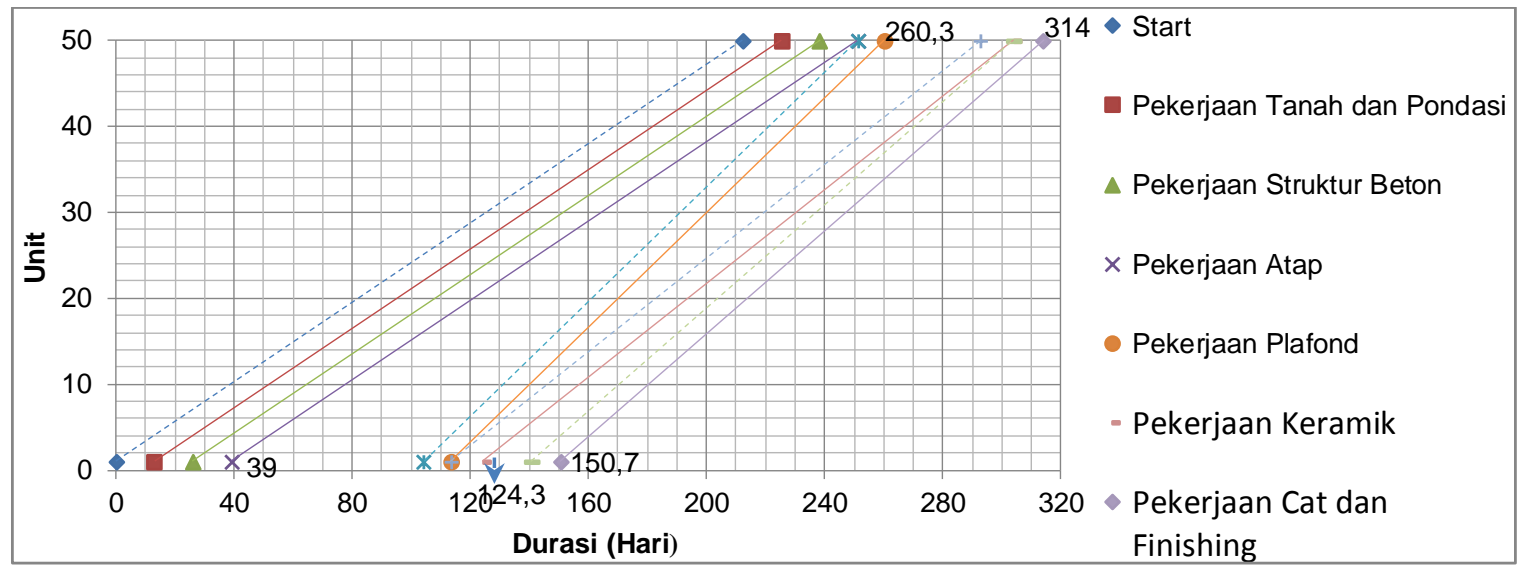

Gambar 8. Simulasi ke-8 dengan Menggunakan Buffer.

\subsubsection{Simulasi Penjadwalan Linier tanpa Time Buffer}

Perincian penggunaan kelompok kerja pada aktivitas yang dijadikan sebagai patokan, yaitu : simulasi $1 \mathrm{~s} / \mathrm{d} 5\left(\mathrm{~F}_{\text {Tanah dan pondasi, beton, atap }}=1,2,3,4,5\right)$, simulasi $6 \mathrm{~s} / \mathrm{d} 10$ ( $\left.\mathrm{F}_{\text {Plafond }}=1,2,3,4,5\right)$, Simulasi $11 \mathrm{~s} / \mathrm{d} 15\left(F_{\text {Keramik }}=1,2,3,4,5\right)$ dan simulasi $16 \mathrm{~s} / \mathrm{d} 20$ ( $\left.F_{\text {Cat dan finishing }}=1,2,3,4,5\right)$. Dengan demikian untuk simulasi penjadwalan linier tanpa menggunakan buffer terdapat 20 simulasi. Namun pada simulasi ini memiliki kelemahan yaitu adanya idle time. Hal ini disebabkan karna setiap simulasi menggunakan satu nilai $m$ sedangkan setiap aktivitas memiliki durasi yang berbeda, akibatnya terjadi idle time pada aktivitas.

Tabel 3. Rangkuman Simulasi Penjadwalan Linier tanpa Menggunakan Buffer.

\begin{tabular}{|c|c|c|c|c|c|c|c|c|c|}
\hline \multirow{2}{*}{$\begin{array}{c}\text { Simulasi } \\
\mathrm{Ke}-. .\end{array}$} & $\begin{array}{c}\text { Jumlah } \\
\text { kelompok }\end{array}$ & $\begin{array}{c}\text { Idle } \\
\text { time }\end{array}$ & $\begin{array}{c}\text { Dur- } \\
\text { asi }\end{array}$ & Inefisiensi & \multirow{2}{*}{$\begin{array}{c}\text { Simulasi } \\
\text { Ke-.. }\end{array}$} & $\begin{array}{c}\text { Jumlah } \\
\text { kelompok }\end{array}$ & $\begin{array}{l}\text { Idle } \\
\text { time }\end{array}$ & $\begin{array}{c}\text { Dur- } \\
\text { asi }\end{array}$ & Inefisiensi \\
\hline & (Kelompok) & (Hari) & (Hari) & (orang-hari) & & (Kelompok) & (Hari) & (Hari) & (orang-hari) \\
\hline ke-1 & 6 kelompok & 441 & 706 & 4704 & ke-11 & 9 kelompok & 1443 & 608 & 18514 \\
\hline ke-2 & 12 kelompok & 432 & 388 & 4608 & ke-12 & 15 kelompok & 638 & 339 & 8048 \\
\hline ke-3 & 18 kelompok & 423 & 282 & 4512 & ke-13 & 21 kelompok & 372 & 249 & 4594 \\
\hline ke-4 & 23 kelompok & 266 & 229 & 2631 & ke-14 & 27 kelompok & 240 & 204 & 2881 \\
\hline ke-5 & 28 kelompok & 173 & 197 & 1767 & ke-15 & 33 kelompok & 162 & 177 & 1875 \\
\hline ke- 6 & 11 kelompok & 1440 & 510 & 16224 & ke-16 & 10 kelompok & 1489 & 559 & 17580 \\
\hline ke-7 & 14 kelompok & 353 & 290 & 3619 & ke-17 & 16 kelompok & 518 & 314 & 5934 \\
\hline ke-8 & 26 kelompok & 408 & 216 & 4844 & ke-18 & 22 kelompok & 200 & 233 & 2121 \\
\hline ke-9 & 32 kelompok & 134 & 180 & 1522 & ke-19 & 31 kelompok & 338 & 192 & 4592 \\
\hline ke-10 & 42 kelompok & 281 & 158 & 3265 & ke-20 & 37 kelompok & 218 & 167 & 2613 \\
\hline
\end{tabular}

Pada simulasi penjadwalan linier tanpa menggunakan buffer (Tabel 3), dipilih Simulasi Ke-9 Pekerjaan plafond dengan penggunaan 4 kelompok kerja yang memiliki durasi dengan nilai idle time dan inefisiensi yang terkecil bila dibandingkan dengan hasil simulasi lainnya. Berikut tabel 4 perhitungan simulasi ke-9 :

Tabel 4. Simulasi ke-9 Pekerjaan Plafond $(F=4)$.

\begin{tabular}{|c|c|c|c|c|c|c|c|c|c|c|}
\hline \multirow{4}{*}{ ID } & \multirow{4}{*}{$\begin{array}{l}\text { Activity / jenis } \\
\text { pekerjaan }\end{array}$} & $d$ & $\begin{array}{c}\mathrm{F} \\
\text { (teoritis) }\end{array}$ & $\begin{array}{c}\mathrm{F} \\
\text { (revisi) }\end{array}$ & 1 & I (Total) & $\mathrm{T}_{1}$ & $\mathrm{~T}_{2}$ & $\mathrm{R}$ & \\
\hline & & $\begin{array}{l}\text { Dur- } \\
\text { asi }\end{array}$ & Group & Group & $\begin{array}{l}\text { Idle } \\
\text { Time }\end{array}$ & $\begin{array}{l}\text { Idle } \\
\text { Time }\end{array}$ & $\begin{array}{c}\text { Durasi unit } \\
\text { ke-1 }\end{array}$ & $\begin{array}{l}\text { Durasi unit } \\
\text { ke-50 }\end{array}$ & & Man-day \\
\hline & & hari & group & group & hari & hari & hari & hari & orang & $\begin{array}{c}\text { orang- } \\
\text { hari }\end{array}$ \\
\hline & & & m.d & m.d & $\begin{array}{c}(\mathrm{F} / \mathrm{m})- \\
\mathrm{d}\end{array}$ & $\begin{array}{c}(50-F) \\
. I\end{array}$ & $\begin{array}{c}\mathrm{T}_{2}- \\
{\left[\left(\mathrm{Q}_{2}-\mathrm{Q}_{1}\right) / \mathrm{m}\right]}\end{array}$ & $\begin{array}{c}{\left[\left(\mathrm{Q}_{2}-\mathrm{Q}_{1}\right) / \mathrm{m}\right]} \\
+\mathrm{T}_{1}\end{array}$ & & Itotal . R \\
\hline 1 & $\begin{array}{l}\text { Pekerjaan Tanah } \\
\text { dan Pondasi }\end{array}$ & 13 & 5,78 & 6 & 0,50 & 22,00 & 13,0 & 123,3 & 12 & 264 \\
\hline 2 & $\begin{array}{l}\text { Pekerjaan Struktur } \\
\text { Beton }\end{array}$ & 13 & 5,78 & 6 & 0,50 & 22,00 & 26,0 & 136,3 & 15 & 330 \\
\hline 4 & Pekerjaan Atap & 13 & 5,78 & 6 & 0,50 & 22,00 & 39,0 & 149,3 & 12 & 264 \\
\hline 5 & Pekerjaan Plafond & 9 & 4,00 & (4) & 0,00 & 0,00 & 48,0 & 158,3 & 12 & 0 \\
\hline 6 & Pekerjaan Keramik & 11 & 4,89 & 5 & 0,25 & 11,25 & 59,0 & 169,3 & 9 & 101,25 \\
\hline 10 & $\begin{array}{l}\text { Pekerjaan Cat dan } \\
\text { Finishing }\end{array}$ & 10 & 4,44 & 5 & 1,25 & 56,25 & 69,0 & 179,3 & 10 & 562,5 \\
\hline & Jumlah & 69 & & 32 & & 133,50 & 133,5 & 179,3 & & 1521,75 \\
\hline
\end{tabular}


[Tingkat produktivitas $(\mathrm{m})=0,44444$ ]

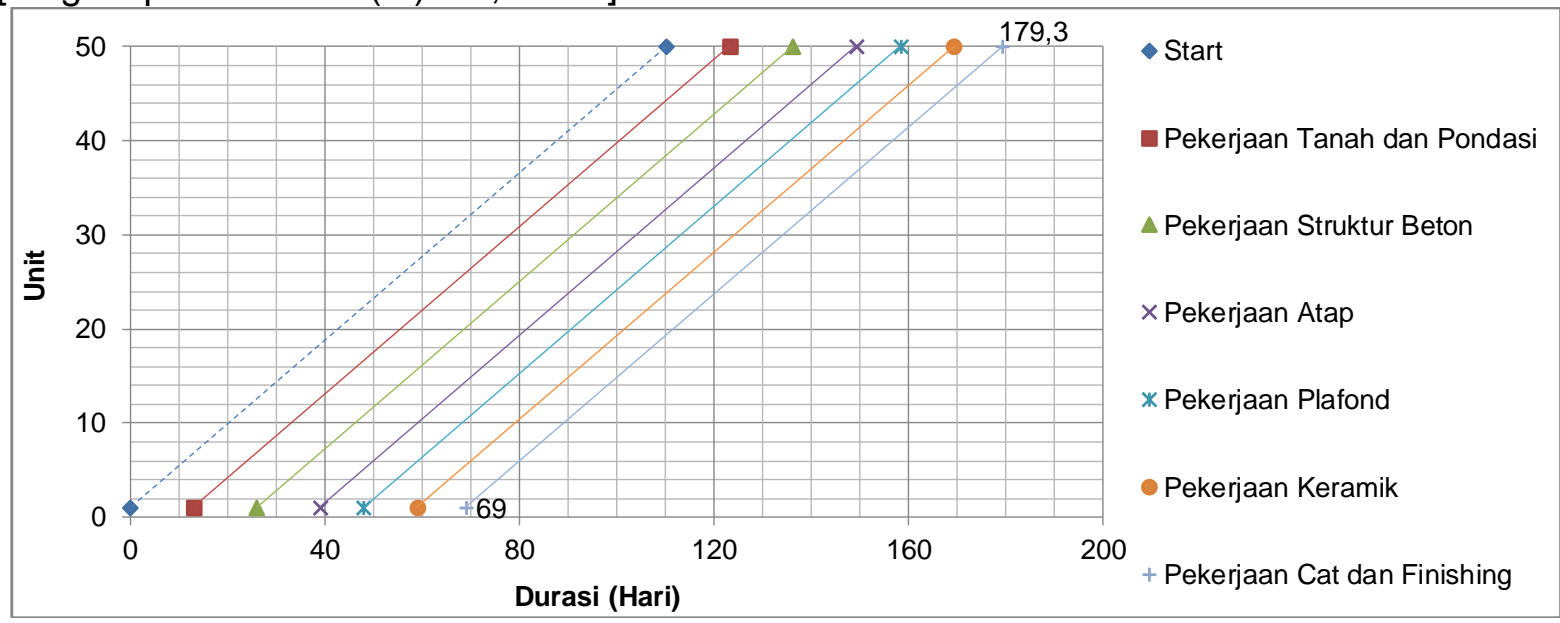

Gambar 9. Simulasi ke-9 Pekerjaan Plafond $(F=4)$.

Dari Gambar 9 dapat dilihat bahwa simulasi ke-9 aktivitas satu dengan aktivitas lainnya dikerjakan secara berkelanjutan dengan menggunakan satu nilai $m$ yaitu : 0,44444 dengan durasi penyelesaian 50 unit yaitu 180 hari. Namun pada simulasi ke-9 terdapat idle time 134 hari yang mengakibatkan terjadinya inefisiensi sebesar 1522 orang hari dengan jumlah pekerja dalam satu kelompok kerja dapat dilihat pada tabel 4. Pada simulasi penjadwalan linier tanpa time buffer dipilih simulasi ke-9 (Tabel 3).

\section{KESIMPULAN}

\subsection{KESIMPULAN}

Dari kedua model simulasi diatas dapat disimpulkan bahwa simulasi ke-8 dengan menggunakan buffermenjadi alternatif pertama yang dipilih, hal ini karena pada simulasi ke-8 hanya menggunakan 18 kelompok kerja, lebih hemat 14 kelompok kerja dari simulasi Ke-9 tanpa menggunakan buffer dengan total 32 kelompok kerja. Hal ini sesuai dengan tujuan penelitian yaitu mencapai penggunaan sumber daya manusia yang efisien.

Pada simulasi ke-8 dengan menggunakan buffer memiliki durasi 314 hari $(<1$ tahun) lebih lama 134 hari dari simulasi Ke-9 tanpa menggunakan buffer yang memiliki durasi 180 hari, namun simulasi ke-8 dengan menggunakan buffer memiliki durasi yang efektif (Idle time $=0$ ) sedangkan pada simulasi Ke-9 tanpa menggunakan buffer memiliki idle time 134 hari dengan inefisiensi 1522 orang-hari (Tabel 4). Selain itu, karena simulasi ke-8 merupakan simulasi penjadwalan linier menggunakan buffer, maka akan memudahkan kontraktor dalam menentukan waktu yang tepat untuk dilakukan mobilisasi pekerja pada setiap aktivitas sehingga mobilisasi pekerja tidak perlu dilakukan pada waktu yang bersamaan untuk semua aktivitas.

\subsection{SARAN}

Dalam penelitian ini, inefisiensi tenaga kerja tidak dihitung berdasarkan masing-masing jenis pekerja namun secara keseluruhan. Dengan demikian diharapkan ada penelitian lanjutan yang melakukan perhitungan inefisiensi tenaga kerja berdasarkan jenis pekerjanya setiap pekerjaan atau sub-pekerjaan memiliki komposisi tenaga kerja yang beragam. Selain itu, pada penelitian lanjutan diharapkan dapat menambahkan unsur biaya sebagai salah satu faktor pembanding dalam memilih dan menentukan penjadwalan yang optimum. Hal ini karena setiap jenis tenaga kerja memiliki biaya yang berbeda-beda.

\section{DAFTAR REFERENSI}

Kass, P.E., and Leong, M.W. (2008). "Linear Schedules for Tunnel Projects." Jacobs Associates. Seattle, WA. 